\title{
Fine structure of Leydig cells in crabeater, leopard and Ross seals*
}

\author{
A. A. Sinha $\dagger$, A. W. Erickson $\ddagger$ and U. S. Seal $\dagger$ \\ $\dagger$ Medical Research Service, Veterans Administration Hospital and Departments of \\ Zoology and Biochemistry, University of Minnesota, Minneapolis, Minnesota, and \\ $\ddagger$ College of Fisheries, University of Washington, Seattle, Washington, U.S.A.
}

\begin{abstract}
Summary. Uitrastructural study of the Leydig cells of nonbreeding crabeater, leopard and Ross seals showed that three types of cells could be distinguished. Type I cells possessed the cytological features typical of steroid-secreting cells. Type II cells exhibited various features of degeneration, e.g. accumulation of large amounts of lipofuscin granules (residual bodies), lipid droplets, secondary lysosomes, rectangular crystalloids, and previously undescribed 'peculiar bodies'. These cellular inclusions and debris were released into the interstitium to be phagocytosed by macrophages and/or resorbed by the lymphatics. Type III Leydig cells contained large amounts of lipid droplets, sparse cytoplasmic organelles and essentially became lipid storage cells.
\end{abstract}

\section{Introduction}

Pinniped Leydig cells have been shown by light microscopy to be clumped and polyhedral with small nuclei and sparse cytoplasm (Harrison, Matthews \& Roberts, 1952; Laws, 1956; Mansfield, 1958; Amoroso et al., 1965; Smith, 1966). Descriptions of the ultrastructure of mammalian Leydig (interstitial) cells have, except for the squirrel monkey (Belt \& Cavazós, 1971), been limited to reproductively active animals (see review by Christensen \& Gillim, 1969; Christensen, 1975). When the cells are involved in testosterone biosynthesis, they usually possess abundant smooth endoplasmic reticulum (ER), mitochondria with tubular cristae, a well developed Golgi complex and variable amounts of lipid droplets. Because the opportunity arose, we investigated the fine structure of the Leydig cells of crabeater, leopard and Ross seals.

\section{Materials and Methods}

Appropriate pieces of testes were obtained from 5 adult crabeater seals (Lobodon carcinophagus), 2 adult leopard seals (Hydrurga leptonyx) and 2 adult Ross seals (Ommatophoca rossi), collected in the Amundsen and Bellinghausen Seas during January and February 1972 (Erickson et al., 1972), and fixed for $2-3 \mathrm{~h}$ in $3 \%$ glutaraldehyde in $0.1 \mathrm{M}$-phosphate buffer, $\mathrm{pH} 7 \cdot 3$, washed twice in $0 \cdot 1 \mathrm{M}$-phosphate buffer on the ship and again later in our laboratory and post-fixed in buffered $2 \%$ osmium tetroxide for 1-2 h. After dehydration with graded ethyl alcohol and two changes in propylene oxide, the tissues were embedded in Epon 812 (Luft, 1961) and sectioned with an LKB Ultratome III. Thin sections were stained with uranyl acetate and lead citrate and examined with an RCA-EMU-3 or 4 electron microscope. Thick sections were stained with methylene blue. Small pieces were also fixed in $10 \%$ phosphate-buffered formalin, embedded in paraffin wax, sectioned at $6-8 \mu \mathrm{m}$ and stained with haematoxylin and eosin, and periodic acid-Schiff (PAS). For each testis, the greatest diameter of 10 Leydig cells was measured by an ocular micrometer.

Blood samples were collected from the animals before death and serum testosterone levels were measured by the radioimmunoassay described by McMillin, Seal, Keenlyne, Erickson \& Jones (1974). Rabbit antiserum for testosterone (testosterone 3-O-carboxymethyl oxime-human serum albumin)

\footnotetext{
* Reprint requests to: Dr A. A. Sinha, Building 49, Room 207, V, A. Hospital, Mịnâholiss, Minnesota 55417, U.S.A. 
yielded a $28 \%$ cross-reaction with $5 \alpha$-dihydrotestosterone, hence some of the activity in the seal serum may have been due to dihydrotestosterone. The between- and within-assay coefficients of variation were $7 \%$ and $2.4 \%$ respectively. The recovery of labelled testosterone samples was greater than $90 \%$, and the blank was $<5 \mathrm{pg}$ per assay tube. The sensitivity was less than $10 \mathrm{ng} / 100 \mathrm{ml}$.

\section{Results}

As well as the Leydig cells, the interstitium between the seminiferous tubules consisted of 3-8 peritubular cells, fibroblasts, macrophages, smooth muscle fibres, collagen fibres, nerves, and blood and lymphatic vessels. The macrophages contained phagocytosed products of the Leydig cells and crystalloids. Some capillaries were fenestrated. The Leydig cells, clustered between the seminiferous tubules, were 11-18 $\mu \mathrm{m}$ in diameter and nuclei were 5-8 $\mu \mathrm{m}$. The cells were polygonal, compact and/or vacuolated (P1. 1, Fig. 1 ; Pl. 2, Fig. 4). With the electron microscope it was seen that the distribution of cytoplasmic organelles and inclusions in the cells varied similarly in the 3 species, and they were classified as cell types I, II and III (P1. 1, Fig. 3; Pl. 2, Figs 5 and 6; PI. 3, Figs 7 and 8; Pl. 4, Fig. 9).

\section{Type I}

These Leydig cells had rod-to-round mitochondria with tubular and/or plate-like cristae, a well developed Golgi complex, moderate amounts of smooth ER, some fenestrated ER, free ribosomes, round nuclei with peripheral heterochromatin and chromatin granules, small amounts of lipid droplets and plicated plasma membranes (P1. 1, Fig. 3; P1. 2, Fig. 5). Some cells possessed membranous whorls of smooth ER, microfilaments, and occasional annulated lamellae (P1. 1, Figs 2 and 3). Close appositions of lipid droplets, mitochondria and smooth ER were also observed (Pl. 1, Fig. 3; Pl. 2, Fig. 5). In some sections, the processes of macrophages were seen closely apposed to the Leydig cell surface and rudimentary desmosomes were sometimes present (P1. 2, Fig. 5).

\section{Type II}

These cells contained multiple areas of focal degeneration and relatively small areas of cells without degenerating cytoplasmic organelles (PI. 4, Fig. 9; P1. 5, Fig. 10). The cells usually contained membrane-bound primary lysosomes, lipofuscin granules, lipid droplets, electron-opaque pigments, previously undescribed 'peculiar bodies', rectangular crystalloids, degenerating mitochondria and highly irregular nuclei. The mitochondrial degeneration began when the primary lysosomes became closely associated with the mitochondrial membrane. At the earliest stage, these mitochondria possessed cristae comparable to those in the Type I cells, but subsequently the lysosome-like material appeared in the mitochondrial matrix and the mitochondrial cristae became sparse (Pl. 4, Fig. 9). Each 'peculiar body' (none observed in cells of Types I and III) had an outer array of short tubules, middle rows of ribosome-like granules, and an inner central cavity (P1. 4, Fig. 9); the tubules were sometimes contiguous with microfilaments, occasionally forming lattice-like patterns. The plasma membrane of the cell had been lost in some places and collagen fibres had penetrated (P1. 3, Fig. 8). Sometimes the entire cell had degenerated and released its product into the interstitium (PI. 5, Fig. 11).

\section{Type III}

These Leydig cells contained many lipid droplets throughout the cytoplasm, occasional mitochondria, sparse smooth ER, a few lysosomes, and had small and irregular nuclei (P1. 2, Fig. 6).

\section{Testosterone concentrations}

Serum testosterone levels were between 112 and $216 \mathrm{ng} / 100 \mathrm{ml}$ in the crabeater seal, $80 \mathrm{ng} / 100 \mathrm{ml}$ in the leopard seals, and 88 and $125 \mathrm{ng} / 100 \mathrm{ml}$ in the Ross seals. 

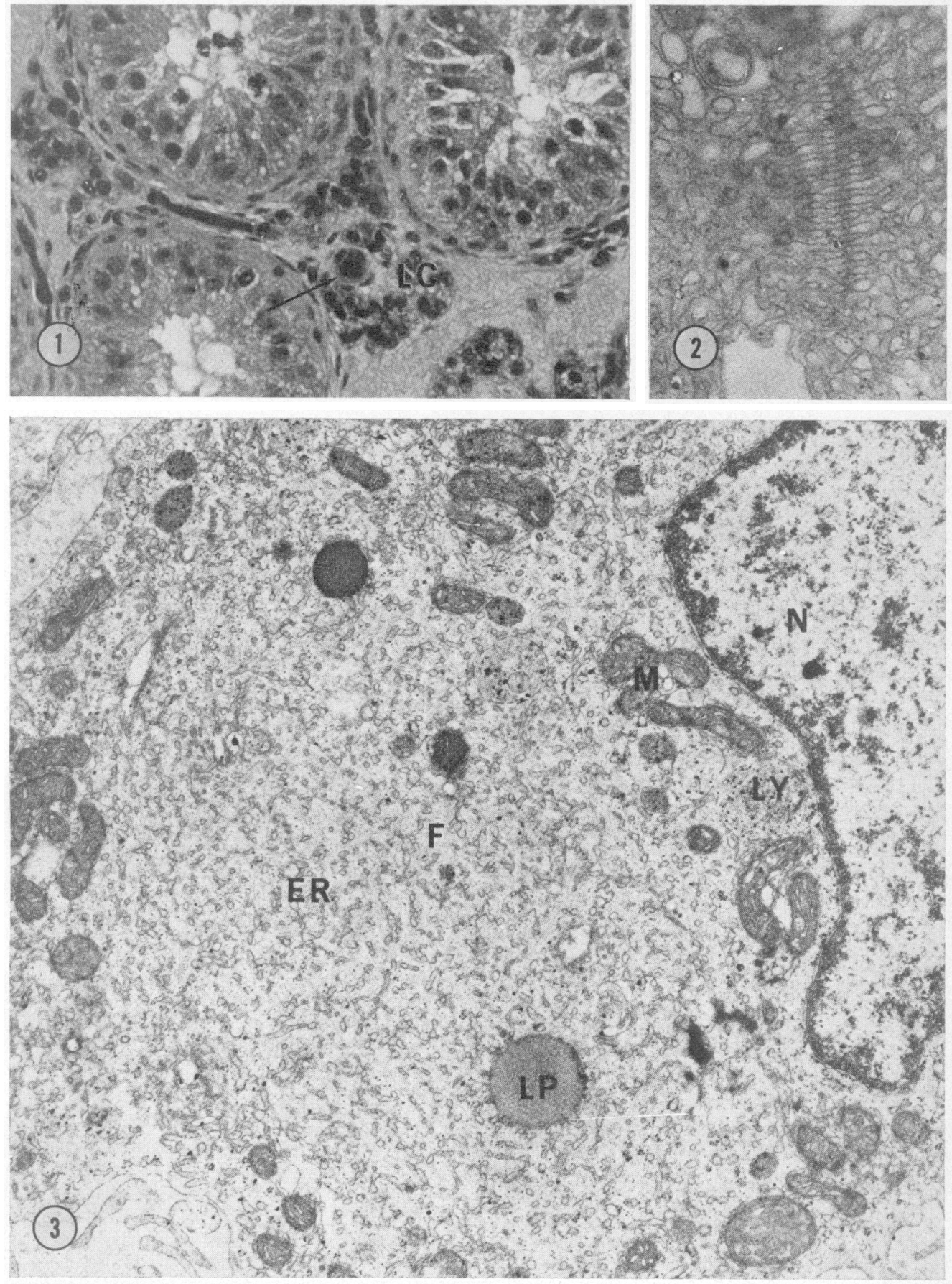

Fig. 1. Seniniferous tubules devoid of spermatids and spermatozoa, Leydig cells (LC) and blood vessels (arrow). Crabeaterseal $21, \mathrm{H} \& \mathrm{E}, \times 385$.

Fig. 2. A Type I Leydigcell with smooth F.R and annulated lamellac. Crabeaterseal $22, \times 31,500$.

Fig. 3. A Type I Leydig cell with nucleus (N), mitochondria (M), abundant smooth endoplasmic reticulum (ER) interspersed with microfilaments (F), occasional lysosomes (LY) and lipid droplets (LP). Ross seal 17, $\times 10,000$. 
PIATE: 2

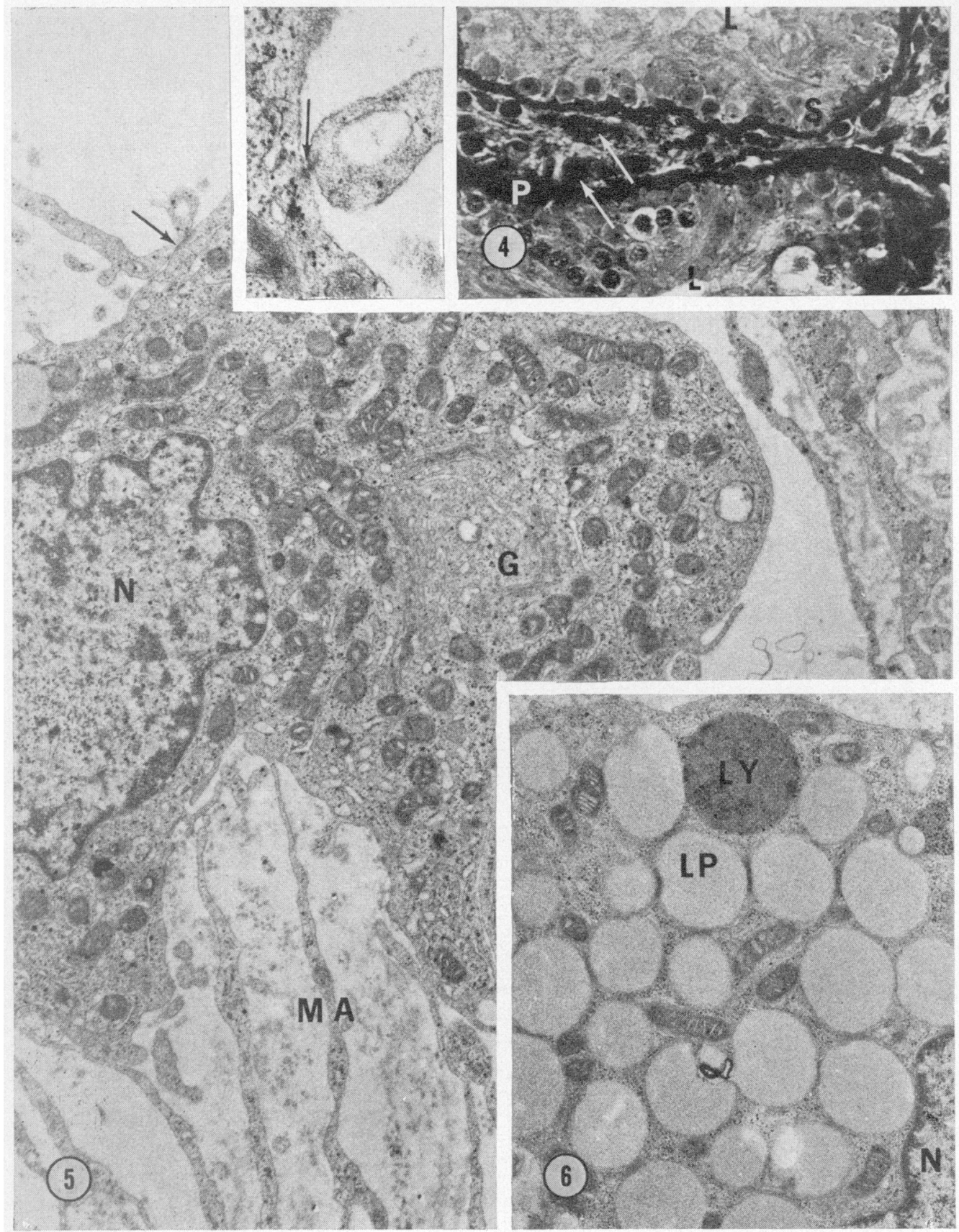

Fig. 4. Portions of two seminiferous tubules, their lumina (L), spermatogonia (S), PAS-positive lamina propria (P), and Leydigcells (arrows). Note absence of spermatids and spermatozoa. Leopard seal $27, \times 400$.

Fig. 5. A Type I Leydig cell which shows nucleus (N), mitochondria with tubular cristae, smooth ER, and a well developed Golgi complex (G). Several macrophage processes (MA) can be seen apposing the cell and occasionally forming rudimentary desmosomes (arrow). Leopard seal 18, $\times 9,300$. Insert: a rudimentary desmosome (arrow) between the process of a macrophage and a Leydig cell. $\times 41,900$.

Fig. 6. A Type III Leydig cell with abundant lipid droplets (L.P), lysosomes (LY), nucleus (N), sparse mitochondria and a relatively smooth plasma membrane. Crabeater seal $26, \times 8,330$. 

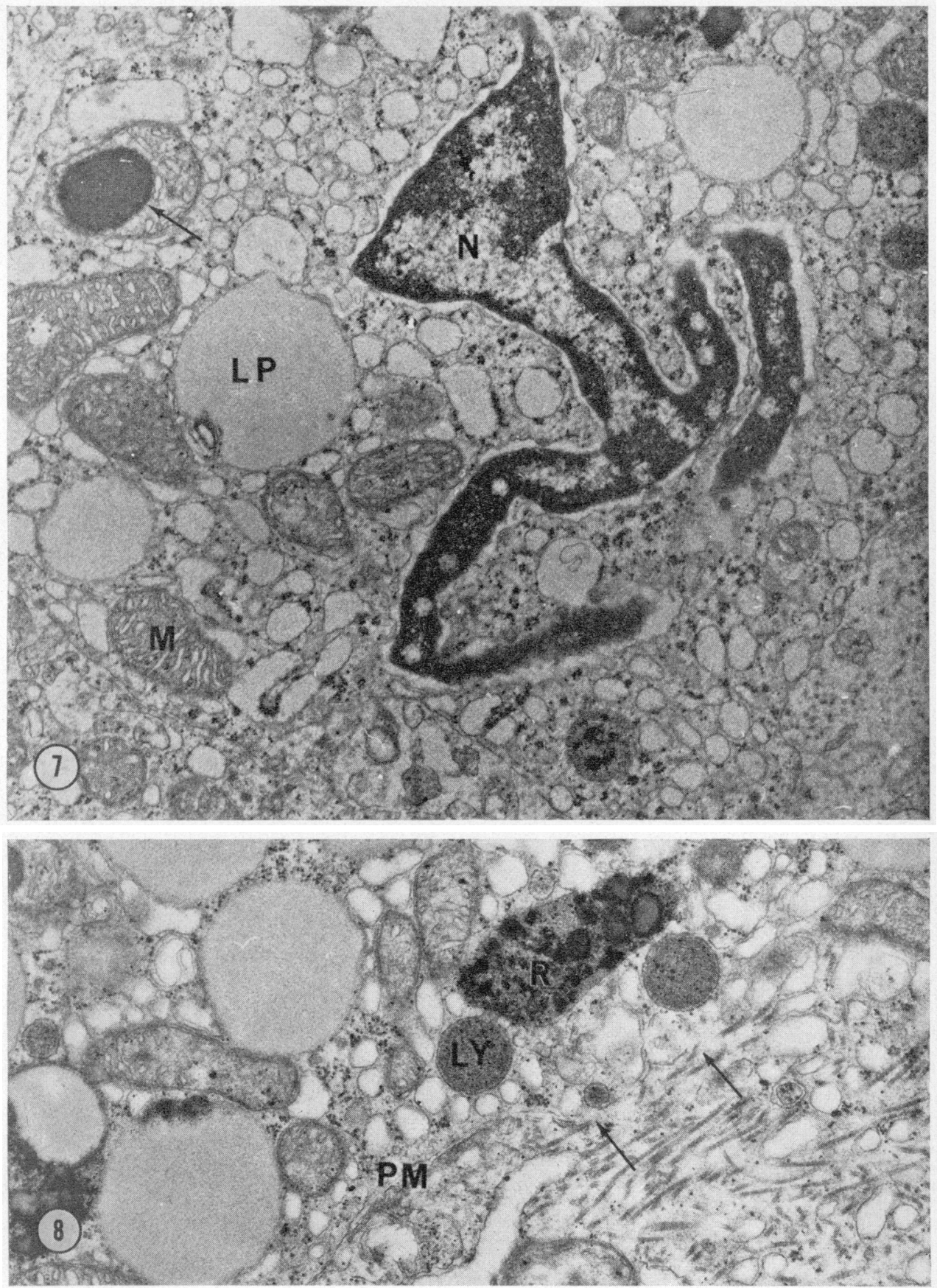

Fig. 7. A portion of a Type ll l.eydigcell showing the highly convoluted nucleus (N). mitochondria (M) with tubular cristate, mitochondria with lipid-like material (arrow), lipid droplets (I.P), and vesieles of smooth FR. Crabeater seal $22 . \times 17.460$.

Fig. 8. A Tipe II Lejdig cell showing portions without plasma membranes (arrows). Note that the collagen tibres have entered the cell. The plasma membrane (PM) is present in some places. The cell contains mant large lipid droplets and lipofuscin granules or residual bodies (R), and membrane-bound lysosomes (LY). Crabeater seal $22 \times 19,580$. 


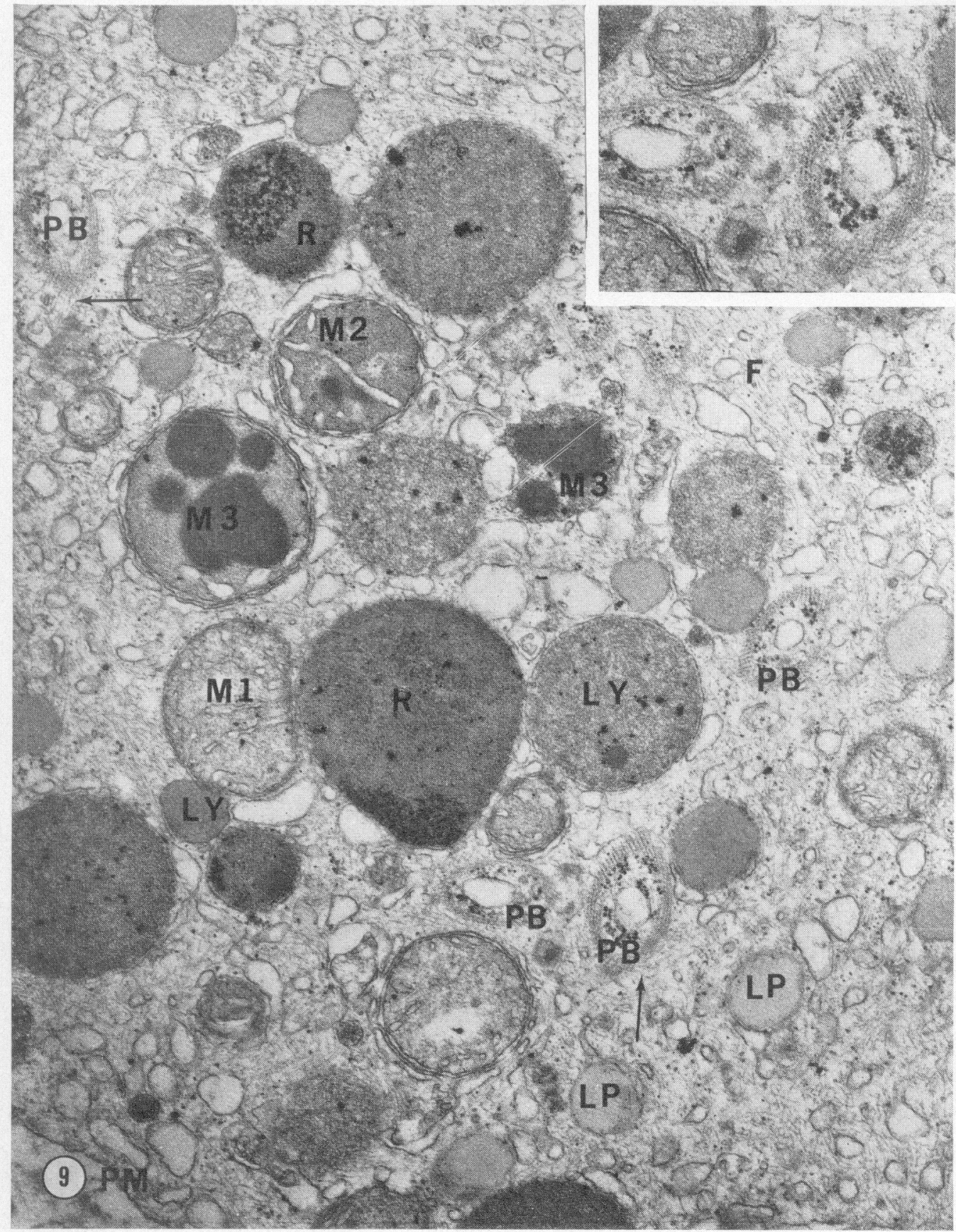

Fig. 9. A Type II Leydig cell illustrating several Jysosomes (LY), mitochondria (MI) associated with lysosomes, mitochondria (M2 and M3) with intramitochondrial electron-opacue material comparable to lysosomes, residual bodies ( R). "peculiar bodies" ( $P B$ ) with arrays of short tubules. smooth ER vesicles, microtilaments ( $F$ ), and a portion of plasma membrane (PM). Degeneration of mitochondria apparently proceeds from stages MI to M.3 which, in the later stages, hate only remnants of mitochondrial cristae. Note that the microfilaments and short tubules are contiguous at the arrows. Ross seal $17, \times 23,430$. Insert: the peculiar body showing close association of short tubules with microlilaments. $\times 38.160$. 
PLATF :
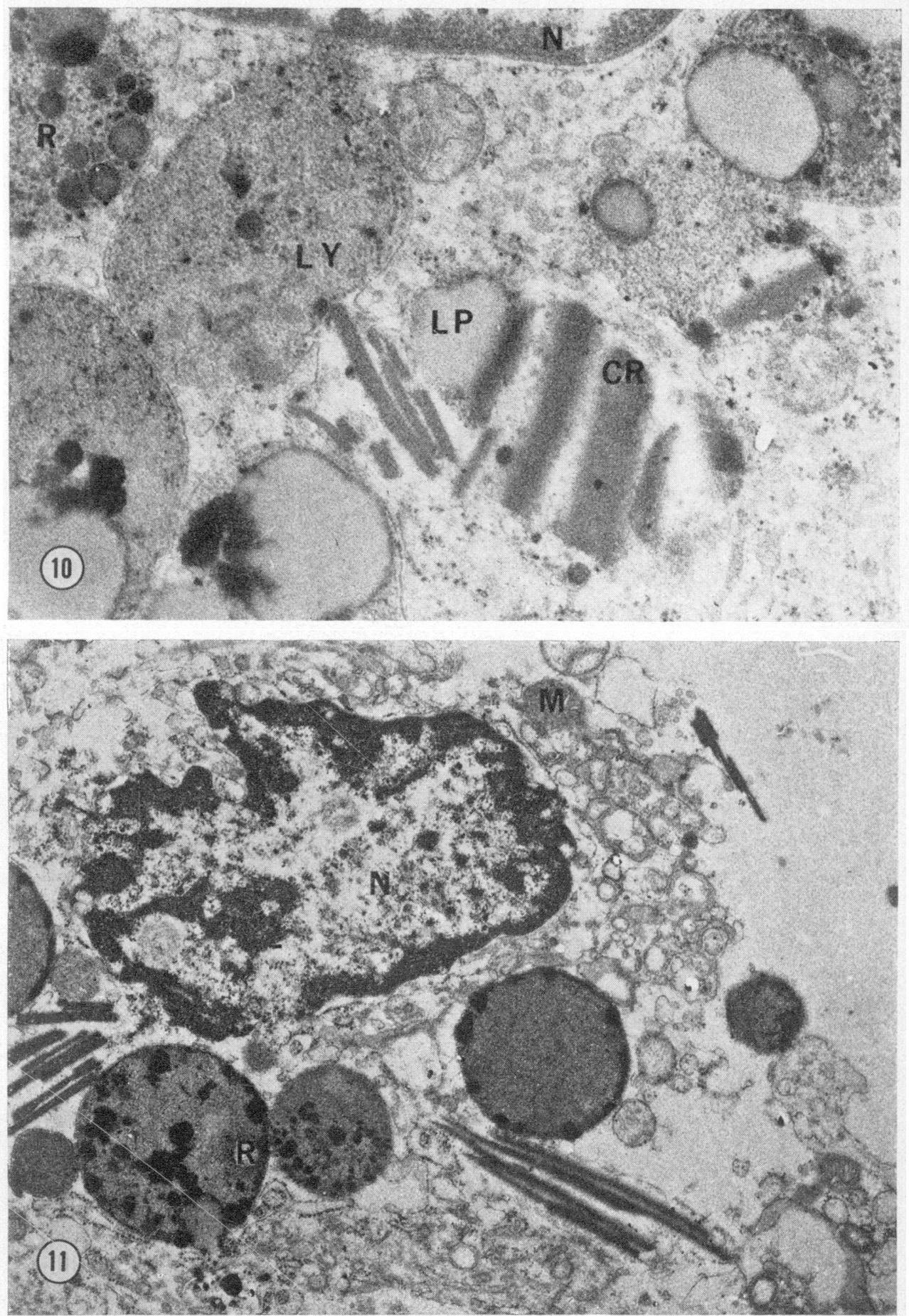

Fig. 10. Part of a Type II Leydig cell illustrating several large residual bodies, nucleus (N), rectangular crystalloids (CR), close association of crystalloids with the lipid droplet (LP), and lysosome (LY). Note the presence of lipid Iroplets and electron-opaque granules in the residual bodies (R). Crabeater seal 21, $\times 33,780$.

Fig. 11. A portion of a degencrating Leydig cell (Type Ii). Note the nucleus (N), mitochondria (M), crystalloids and some residual bodies $(R)$. The smooth $\mathbf{R}$ is poorly preserved in this cell, but adjacent Leydig cells were well preserved. Ross seal 17, $\times 14,380$. 


\section{Discussion}

Earlier studies on reproduction in pinnipeds have suggested that crabeater seals breed in October, and leopard and Ross seals in November (Bertram, 1940; Harrison et al., 1952; Mansfield, 1958; Smith, 1966; Øritsland, 1970). However, there are no published records of observed breeding in any of the three species (Erickson \& Hofman, 1974). Our specimens were obtained after the presumed breeding season, and all the seals investigated were azoospermic, as shown by histology of the seminiferous tubules and epididymis and by smears of the testis and epididymis, confirming the non-breeding condition of the animals.

Our study has shown that only the Leydig cells of Type I possess the cytological features considered essential for testosterone biosynthesis in mammals (Christensen \& Gillim, 1969; Sinha \& Seal, 1969; Christensen, 1975), and their relative sparsity suggests that testosterone secretion was probably low.

Areas of focal degeneration, usually representing 'wear and tear' of the cells, have been reported for the Leydig cells of reproductively active animals (Christensen \& Gillim, 1969; Christensen, 1975), but in the squirrel monkey during seasonal regression the Leydig cells possessed large numbers of residual bodies and lipid droplets (Belt \& Cavazós, 1971). These authors suggested that the residual bodies were formed because of lysosomal activity. We found numerous Leydig cells undergoing degeneration in the seals during the postbreeding season and in some degenerating cells there were close associations of mitochondria and smooth ER with the lysosomes. The degenerating organelles apparently formed lipofuscin granules when associated with lipid droplets and lysosomes. Subsequently, the cellular inclusions and debris were phagocytosed by the macrophages and/or resorbed by the lymphatics or blood vessels. In contrast, the cells undergoing only partial degeneration (Type III) accumulated large amounts of lipid droplets and possessed sparse cytoplasmic organelles. Occasional Leydig cells with large amounts of lipid droplets have been observed in reproductively active animals (Christensen \& Gillim, 1969; Sinha \& Seal, 1969; Connell \& Christensen, 1975).

We thank Mr Michael D. Bentley and Mr Francis Pomroy, Jr for technical help; Mr Jack Otis and Mr R. J. Oehlenschlager for field assistance; Dr G. A. Petrides, Dr J. R. Gilbert and the logistic support of the U.S. Coast Guard Cutter 'Southwind'; and Lois Center for secretarial assistance.

This research was supported in part by National Science Foundation Grants G.U. 30270 and G.U. 29829X from the Office of Polar Programs and by NIH Grant 5 R01 AM11-376.

\section{References}

Amoroso, E.C., Bourne, G.H., Harrison, R.J., MatThews, L.H., Rowlands, I.W. \& Sloper, J.C. (1965) Reproductive and endocrine organs of foetal, newborn, and adult seals. J. Zool., Lond. 147, 430-486.

BeLT, W.D. \& Cavazós, L.F. (1971) Fine structure of the interstitial cells of Leydig in the squirrel monkey during seasonal regression. Anat. Rec. 169, 115-128.

Bertram, G.C.L. (1940) The biology of the Weddell and crabeater seals, with a study of the comparative behavior of the pinnipedia. Scient. Rep. Graham Land Exped. 1934-37, Vol. I, Pt. 1, pp. 1-139. Br. Mus. Nat. Hist., London.

Christensen, A.K. (1975) Leydig cells. In Handbook of Physiology, Male Reproductive System, Vol. 5, Sect. 7, Chap. 3, pp. 57-94. Eds D. W. Hamilton \& R. O. Greep. American Physiological Society, Washington, D.C.
Christensen, A.K. \& Gillim, S.W. (1969) The correlation of fine structure and function in steroidsecreting cells with emphasis on those of the gonads. In The Gonads, pp. 415-488. Ed. K. W. McKerns. Appleton-Century-Crofts, New York.

Connell, C.J. \& Christensen, A.K. (1975) The ultrastructure of the canine testicular interstitial tissue. Biol. Reprod. 12, 368-382.

Erickson, A.W., Gilbert, J.R., Petrides, G.A., Oehlenschlager, R.J., Sinha, A.A. \& Otis, J. (1972) Population of seals, whales and birds in the Bellinghausen and Amundsen seas. Antarct. J. U.S. 7, 70-72.

ErICKSON, A.W. \& Hofman, R.J. (1974) Antarctic seals. In Antarctic Map Folio Series, No. 18, pp. 4-13. Ed. V.C. Bushnell. American Geographical Society Publishing, New York. 
Harrison, R.J., Matthews, L.H. \& Roberts, J.M. (1952) Reproduction in some Pinnipedia. Trans. zool. Soc. Lond. 27, 437-540.

LAws, R.M. (1956) The elephant seal (Mirounga leonina Linn.). 2. General, social, and reproductive behaviour. Scient. Rep. Falkld Isl. Depend. Surv. 13, 1-88.

LUFT, J.H. (1961) Improvements in epoxy resin embedding methods. J. biophys. biochem. Cytol. 9, 409414.

MANSFIELD, A.W. (1958) The breeding behaviour and reproductive cycle of the Weddell seal (Leptonychotes Weddelli Lesson). Scient. Rep. Falkld Isl. Depend. Surv. 18, 1-41.
McMillin, M.J., Seal, U.S., Keenlyne, K.D., ERickson, A.W. \& Jones, J.E. (1974) Annual testosterone rhythm in the adult white-tailed deer (Odocoileus virginianus borealis). Endocrinology 94, 1034-1040.

OrITSLAND, T. (1970) Sealing and seal research in the Southwest Atlantic pack ice, September-October 1964. In Antarctic Ecology, Vol. 1, pp. 367-376. Ed. M. W. Holdgate. Academic Press, London.

Sinha, A.A. \& Seal, U.S. (1969) The testicular interstitial cells of a lion and a three-toed sloth. Anat. Rec. 164, 35-46.

SMItH, M.S.R. (1966) Studies on the Weddell seal in McMurdo Sound, Antarctica. Ph.D. thesis, University of Canterbury.

Received 21 May 1976 